\title{
Hubungan Kepuasan Mutu Pelayanan Immunisasi Dasar Terhadap Loyalitas Ibu Balita
}

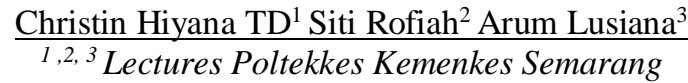 \\ Corresponding author: Christin Hiyana TD \\ Email: christinhiyana@yahoo.com
}

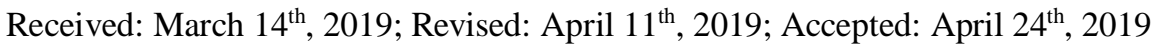

\begin{abstract}
Immunization is an attempt to provide immunity to infants and children by inserting vaccines into the body so that the body makes substances anti to prevent certain diseases. The purpose of immunization is to stimulate the body's immunological system to form specific antibodies so that it can protect the body from attacks that can be prevented by immunization (PD3I)(Lestari W, Margawati A, 2014) In 2015, 292 districts / cities (56.8\%) had reached $80 \%$ of complete basic immunization in infants, thus the target of the RPJMN in 2015 of $75 \%$ was not achieved(Kemenkes RI, 2015). This research is analytic survey with cross sectional approach. Samples were mothers of babies who came to the Puskesmas to get immunization services at Mungkid Health Center as many as 123 respondents. Bivariate analysis used statistical tests Chi-Square.The results showed that the satisfaction of the quality of basic immunization services for mothers of children under five was mostly in the category of 105 respondents satisfied (85.4\%), the loyalty of mothers of children under five in the immunization category was 133 respondents (91.9\%) and there was no relationship between satisfaction quality of basic immunization services with maternal loyalty of children under five in immunization with $p$-value $=0.163$. Puskesmas to provide information, especially about side effects or information related to post-immunization follow-up events to reduce anxiety rates for mothers who will do immunization.
\end{abstract}

Keyword: Satisfaction; loyalty; immunization

\section{Pendahuluan}

Imunisasi merupakan suatu usaha memberikan kekebalan pada bayi dan anak dengan cara memasukkan vaksin kedalam tubuh agar tubuh membuat zat anti untuk mencegah penyakit tertentu. Tujuan imunisasi adalah merangsang sistim imunologi tubuh untuk membentuk antibodi spesifik sehingga melindungi tubuh dari serangan Penyakit Yang Dapat Dicegah Dengan Imunisasi (PD3I)(Lestari W, Margawati A, 2014).

Pemerintah Indonesia sangat mendorong pelaksanaan program imunisasi sebagai cara untuk menurunkan angka kesakitan, kematian pada bayi, balita/anak-anak pra sekolah. Tujuan pemberian imunisasi yaitu diharapkan anak menjadi kebal terhadap penyakit sehingga dapat menurunkan angka morbiditas dan mortalitas serta mengurangi kecacatan akibat penyakit(Hidayat, 2008).

Imunisasi dasar adalah pemberian imunisasi awal pada bayi untuk mencapai kadar kekebalan di atas ambang perlindungan(Depkes RI, 2012). Jenis- jenis imunisasi dasar, yaitu: $B C G$, yaitu imunisasi dasar yang diberikan untuk mencegah penyakit TBC. Imunisasi dasar
Hepatitis $B$ diberikan untuk mencegah penyakit hepatitis B. Vaksin DPT diberikan untuk mencegah penyakit difteri, pertusis, dan tetanus. Imunisasi Campak diberikan untuk mencegah penyakit campak dan Polio untuk mencegah penyakit polio(IDAI, 2014).

Cakupan immunisasi dasar lengkap periode 2008-2011, dibandingkan dengan cakupan periode 2012-2015 di Indonesia mengalami penurunan. Cakupan immunisasi dasar lengkap berdasarkan data rutin pada tahun 2010 - 2013 mencapai target Renstra Kementrian Kesehatan. Namun pada tahun 2014 - 2015 cakupan immunisasi tidak mencapai cakupan target renstra yang diharapkan. Indikator RPJMN untuk program immunisasi yaitu presentase kabupaten / kota yang mencapai $80 \%$ immunisasi dasar lengkap pada bayi. Pada tahun 2015 sebanyak 292 kabupaten/kota $(56,8 \%)$ telah mencapai $80 \%$ immunisasi dasar lengkap pada bayi, dengan demikian target RPJMN pada tahun 2015 sebesar $75 \%$ tidak tercapai(Kemenkes RI, 2015). Salah satu faktor yang perlu diperhatikan dalam imunisasi adalah loyalitas jadwal imunisasi. 
Apabila ibu tidak patuh dalam mengimunisasi bayinya maka akan berpengaruh terhadap kekebalan dan kerentanan bayi terhadap suatu penyakit. Sehingga bayi harus mendapatkan imunisasi tepat waktu agar terlindung dari berbagai penyakit berbahaya(Ranuh, 2008).

\section{Metode Penelitian}

Jenis penelitian ini adalah survey analitik dengan pendekatan cross-sectional. Populasi pada penelitian ini adalah semua ibu bayi yang melakukan kunjungan imunisasi ke Puskesmas Mungkid pada bulan Oktober 2017 sejumlah 123 responden. Instrumen penelitian ini menggunakan kuesioner tentang kepuasan dan loyalitas ibu balita. Analisa univariat untuk mengetahui prosentase kepuasan mutu pelayanan immunisasi dasar dan loyalitas / kepatuhan ibu balita. Analisa bivariat uji statistik menggunakan Chi-Square.

\section{Hasil Dan Pembahasan}

\section{Kepuasan Mutu Pelayanan Imunisasi}

Tabel 1

Distribusi Frekuensi Kepuasan Mutu Pelayanan Responden

\begin{tabular}{clcc}
\hline No & Kepuasan & F & \% \\
\hline 1 & Tidak Puas & 18 & 14.6 \\
2 & Puas & 105 & 85.4 \\
& Jumlah & $\mathbf{1 2 3}$ & $\mathbf{1 0 0}$ \\
\hline
\end{tabular}

Kepuasan mutu pelayanan immunisasi dinilai dari 4 dimensi meliputi dimensi pelayanan, dimensi desain, kecemasan atau tampilan, dimensi bisnis, dan dimensi emosional.

Daya tanggap merupakan salah satu dimensi mutu pelayanan yang dapat mempengaruhi kepuasan pasien. Komunikasi kepada pasien mengenai proses pelayanan yang diberikan akan membentuk persepsi yang lebih positif. Salah satunya adalah kesigapan dan ketulusan dalam menjawab pertanyaan atau permintaan pasien (Lee H, Delene LM, 2000).

Pemberian informasi akan efek samping, prosedur pelayanan immunisasi menjadi hal yang penting bagi ibu, berkaitan dengan psikologi ibu ketika menghadapi efek samping yang mungkin muncul karena pemberian vaksin immunisasi. Panas, anak menjadi rewel dan ketidaknyamanan yang dirasakan anak menjadi kendala dan ketakutan yang sering dirasakan oleh ibu pasca immunisasi. Jika tidak diantisipasi maka dikhawatirkan akan menyebabkan keengganan ibu untuk kembali mengimunisasikan anaknya.
Assurance adalah kemampuan dan keramahan serta sopan santun pegawai dalam meyakinkan kepercayaan konsumen. Ibu seringkali mengalami dilema dalam mengimunisasikan bayinya, disatu sisi ibu ingin anaknya sehat terhindar dari penyakit, namun disisi lain banyak rumor yang beredar terkait dengan sisi buruk immunisasi, seperti rumor tentang halal atau haram vaksin yang diberikan, ataupun efek samping yang terjadi yang akan merugikan dan menyebabkan kesakitan pada anak. Penjelasan tenaga kesehatan tentang immunisasi secara menyeluruh untuk meyakinkan kepercayaan ibu mutlak diperlukan, karena jika tidak diberikan penjelasan secara memadai maka informasi yang keliru dan rumor negatif berkaitan dengan immunisasi akan menjadi hal yang menghambat pencapaian target immunisasi.

\section{Loyalitas Ibu Balita}

Tabel 2

Distribusi Frekuensi Loyalitas Ibu Balita

\begin{tabular}{clcc}
\hline No & \multicolumn{1}{c}{ Loyalitas } & F & \% \\
\hline 1 & Tidak Loyal & 10 & 8.1 \\
2 & Loyal & 113 & 91.9 \\
& Jumlah & $\mathbf{1 2 3}$ & $\mathbf{1 0 0}$ \\
\hline
\end{tabular}

Pada pelayanan immunisasi loyalitas ibu ditunjukkan dengan keinginan ibu untuk kembali mengimunisasikan bayinya sesuai dengan standar yang ditetapkan. Perilaku Kebiasaan (Habitual Behavior) dalam immunisasi diperlukan dalam kaitannya dengan jadwal immunisasi yang berulang dan lebih dari sekali. Kondisi yang berkaitan dengan anak rewel pasca immunisasi, anak menjadi panas dan bagaimana petugas melakukan antisipasi terhadap kejadian ikutan pasca immunisasi (KIPI) akan mempengaruhi loyalitas ibu untuk datang kembali mengimunisasikan bayinya.

Faktor lain dari loyalitas adalah komitmen (Commitment), komitment dalam loyalitas pelayanan immunisasi berkaitan dengan komitment ibu untuk kembali sesuai tanggal atau jadwal yang ditentukan. Kembalinya ibu untuk mendapatkan immunisasi di Puskesmas memudahkan dalam melakukan kontrol terhadap kelengkapan immunisasi.

Loyalitas dalam penelitian ini juga dilihat dari kelengkapan ibu dalam mengimunisasikan bayinya, sesuai dengan usia bayinya. Kontrol petugas terhadap kunjungan dan ketepatan waktu 
ibu melakukan immunisasi sesuai dengan usia bayinya. Dengan kembali datang mengimmunisasikan bayinya maka kelengkapan akan didapatkan, sehingga loyalitas ibu dapat dirasakan.

\section{Kepuasan Mutu Pelayanan Imunisasi Dasar dan Loyalitas Ibu Balita}

Tabel 3

Hubungan Kepuasan Mutu Pelayanan Immunisasi Dasar terhadap Loyalitas Ibu Balita

\begin{tabular}{lcccccc}
\hline \multirow{2}{*}{ Kepuasan } & \multicolumn{5}{c}{ Loyalitas } \\
\cline { 2 - 7 } & $\begin{array}{l}\text { Tidak } \\
\text { Loyal }\end{array}$ & \multicolumn{2}{c}{ Loyal } & \multicolumn{2}{c}{ Total } \\
\cline { 2 - 7 } & F & $\%$ & F & $\%$ & F & $\%$ \\
\hline Tidak Puas & 3 & 16,7 & 15 & 83,3 & 18 & 100 \\
Puas & 7 & 6,7 & 98 & 93,3 & 105 & 100 \\
p value $=0,163$ & & & & \\
\hline
\end{tabular}

Berdasarkan tabel 3 hasil menunjukkan bahwa responden tetap akan loyal melaksanakan imunisasi dalam keadaan puas maupun tidak puas terhadap layanan Puskesmas. Hal ini juga sesuai dengan analisa uji hubungan antara kepuasan dengan loyalitas melaksanakan imunisasi dengan menggunakan uji Chi-Square diperoleh $\mathrm{p}$ value $=$ 0,163 ( $p>0,05$ ) berarti dapat disimpulkan bahwa tidak ada hubungan antara Kepuasan Mutu Pelayanan Immunisasi Dasar terhadap Loyalitas Ibu Balita.

Hal ini menunjukkan bahwa responden tetap akan loyal melaksanakan imunisasi dalam keadaan puas maupun tidak puas terhadap layanan Puskesmas. Sehingga dapat disimpulkan bahwa tidak ada hubungan antara Kepuasan Mutu Pelayanan Immunisasi Dasar terhadap Loyalitas Ibu Balita. Kepuasan sebagai salah satu komponen yang mempengaruhi loyalitas. Peraturan tentang jadwal immunisasi dari Pemerintah membuat ibu dipaksa untuk mematuhi aturan tersebut. Fasilitas yang diberikan pemerintah antara lain biaya gratis, kemudahan dalam mendapatkan immunisasi baik di Posyandu maupun di Puskesmas dan adanya bulan immunisasi membuat ketercakupan target immunisasi menjadi besar. Kelengkapan immunisasi dapat lebih mudah dicapai.

Riset tentang faktor yang berhubungan dengan kelengkapan imunisasi dasar pada bayi di Puskesmas Banyudono Kabupaten Boyolali di dapatkan hasil bahwa pengetahuan dan motivasi ibu berpengaruh positif terhadap kelengkapan imunisasi dasar, sedangkan tingkat pendidikan dan jarak rumah tidak mempunyai pengaruh terhadap kelengkapan imunisasi dasar (Ningrum, 2008). Hasil penelitin tentang kelengkapan immunisasi dasar anak balita didapatkan faktor yang berpengaruh dalam kelengkapan immunisasi adalah pendidikan orang tua sebagian besar berpendidikan menengah $(58,4 \%)$, pendapatan $(85,5 \%)$ dan pengetahuan orang tua sebagian besar baik dan sebagian besar sikap orang tua baik (96,2\%). Ketidaklengkapan immunisasi dikarenakan orang tua tidak tahu jadwal immunisasi $(34,8 \%)$ dan anak sakit ketika hendak diimunisasi $(28,4 \%)$ (Mathilda, 2009).

\section{Simpulan}

Hasil penelitian menunjukkan tidak ada hubungan antara kepuasan mutu pelayanan immunisasi dasar dengan loyalitas ibu balita dalam pelaksanaan immunisasi. Diharapkan petugas memberikan informasi tentang efek samping berkaitan dengan kejadian ikutan pasca immunisasi untuk menurunkan angka kecemasan ibu yang akan melakukan immunisasi.

\section{Daftar Pustaka}

Depkes RI. (2012). Stimulasi Tumbuh Kembang Balita dan Anak Prasekolah. Pedoman Penatalaksanaan Stimulasi, Deteksi, dan Intervensi Dini Tumbuh Kembang Anak Di Tingkat Pelayanan Kesehatan Dasar. Jakarta: Depkes RI.

Hidayat, A. . (2008). Ilmu Keperawatan Anak I (S. Medika, ed.). Jakarta.

IDAI. (2014). Pedoman Imunisasi di Indonesia. Jakarta: Badan Penerbit Ikatan Dokter Anak Indonesia.

Kemenkes RI. (2015). INFODATIN Pusat Data dan Informasi Kemeterian Kesehatan RI Situasi Kesehatan Remaja. Jakarta: Kementerian Kesehatan.

Lee H, Delene LM, B. M. (2000). Methods of measuring health-care service quality. J Busn Res.

Lestari W, Margawati A, and Z. R. (2014). Faktor risiko stunting pada anak umur 6-24 bulan di kecamatan Penanggalan kota Subulussalam provinsi Aceh. Jurnal Gizi Indonesia, 3.1.

Mathilda, A. (2009). Kelengkapan Immunisasi Dasar Anak Balita Dan Faktor - Faktor Yang Berhubungan Di Poliklinik Ilmu Kesehatan Anak Rumah Sakit Umum Pusat 
Nasional Cipto Mangunkusumo. Retrieved from

http://lib.ui.ac.id/file?file=digital/123243S09081f Kelengkapan imunisasiHA.pdf9081f

Ningrum, E. P. \& S. (2008). Faktor-Faktor Yang Mempengaruhi Kelengkapan Imunisasi
Dasar Pada Bayi Di Puskesmas Banyudono Kabupaten Boyolali. UMS Journal, 1, 7-12.

Ranuh, I. G. . (2008). Pedoman Imunisasi di Indonesia. Jakarta: Badan Penerbit Ikatan Dokter Anak Indonesia. 